\title{
Testing Soil Accumulation of Cd from Reclaimed Water
}

\author{
SIHENG SUN ${ }^{1 *}$, GUOZHONG HUANG ${ }^{2}$, JIARAN CAI ${ }^{2}$, DONG JIANG ${ }^{2}$ \\ ${ }^{1}$ Beijing Institute of Petrochemical Technology, College of Safety Engineering, Daxing District, Qingyuan Northroad \\ No.19, 102617, Beijing, China \\ ${ }^{2}$ University of Science and Technology Beijing, College of Civil and Resource Engineering, Haidian District, Xueyuan \\ Road No.30, 100083, Beijing, China
}

\begin{abstract}
The reuse of wastewater improves the comprehensive utilization of water resources, and reduces the shortage of water resources. In this paper, the accumulation of heavy metal Cd risk in reclaimed water irrigated soil to human health was analysised through experiments and simulations. Firstly, according to the static adsorption experiment of sandy clay loam, the fitting effect of Freundlich equation on $C d$ is better for the certainty coefficient $R^{2}$ reaches 0.97 . Then, use the more accurate DEM model of CXTFIT2.1 software to fit the $\mathrm{Cl}^{-}$penetration curve. Finally, made the heavy metal leading experiment, found that the TSM model has a good fitting effect on the penetration curve of $C d$, with a determination coefficient close to 1 and a small standard error coefficient. Based on the results of the above experiments, the HYDRUS-1D was used to analyze and predict the cumulative risk of $C d$ in reclaimed water irrigated soil. The results showed that: after 100 years under current situations, the predicted concentration of $\mathrm{Cd}$ in soil may reach $0.742 \mathrm{mg} / \mathrm{kg}$, which exceeded the national soil environmental quality standard, may be a serious health hazard. Measures should be taken to reduce the risk of human health by ingestion and accumulation of crops and vegetables.
\end{abstract}

Keywords: reclaimed water irrigated soil; heavy metal Cd; human health; cumulative risk

\section{Introduction}

The reuse of wastewater improves the comprehensive utilization of water resources and reduces the shortage of water resources [1-3]. However, there are many problems in the application process. When the wastewater was used in agricultural irrigation, heavy metal ions in reclaimed water may be enriched into vegetables and crops. Heavy metal Cd has strong mobility transfer from soil to vegetable [4-10], and may be combined with phosphate groups or chlorine containing bases in DNA and RNA after entering the human body [11-13]. Excessive accumulation of $\mathrm{Cd}$ in the body can cause lung and kidney dysfunction and may be harmful to human health through food intake [14].

In recent years, the accumulation of heavy metal $\mathrm{Cd}$ in soil and its impact on agricultural product safety has become a major concern of the scientific community, government and society, and the sustainable development of the environment [15-17]. Many scholars at home and abroad have carried out a great deal of research on the transport rule of heavy metal ions in soil. Scuntjens et al. studied the aging effects on Cadmium transport in undisturbed contaminated sandy soil columns [18]. Daniel et al. studied the migration behavior of $\mathrm{Cd}$ in soil under different concentration conditions using sequential extraction, batch, and miscible displacement experiments [19]. Gu et al. collected soil of different levels and depths, measured the content of $\mathrm{CD}, \mathrm{Pb}$ and $\mathrm{Ni}$ in the soil, and discussed the enrichment characteristics and migration rules of $\mathrm{CD}, \mathrm{Pb}$ and $\mathrm{Ni}$ in the soil [20]. $\mathrm{Lu}$ et al. studied the effects of exogenous organic acids on soil $\mathrm{pH}$, enzyme activity, and cadmium migration and transformation [21]. Pang et al. [22], through indoor soil column penetration test, studied the migration rule of $\mathrm{Pb} / \mathrm{Cd} / \mathrm{Zn}$ under 3-60m/d pore water velocity, and used CXTFIT software to fit experimental data to obtain migration parameters. Dube et al. summarized the model methods of soil adsorption and migration of

*email: siheng@bk.ru, jiushiwossh@163.com 
modern heavy metals, including soil column experiment method and artificial neural network based on data fitting [23]. In addition, there are many studies on the accumulation characteristics and rules of heavy metals from soil to plants. Ru et al., [24] studied the migration and accumulation of heavy metal $\mathrm{Cu}, \mathrm{Zn}, \mathrm{Pb}$ and $\mathrm{Cd}$ in the soil radish system using greenhouse soil culture pot experiments. Wei, et al. [15], studied the accumulation and distribution characteristics of soil heavy metal $\mathrm{Cd}$ in cassava, and discussed the safety critical value of cassava in the environment polluted by $\mathrm{Cd}$. There are also many studies on the migration of heavy metal $\mathrm{Cd}$ in the soil plant system [25,26]. In Japan's Minamata disease event, inorganic mercury in seawater into methyl-mercury, fish intake is cumulative, people food poisoning, the heavy metal bioaccumulation, may cause human health risk [27]. Y.X. Zhang, et al. also showed that $\mathrm{Cd}$ is one of the main factors of soil pollution. Trace $\mathrm{Cd}^{2+}$ not only has a toxic effect on plant growth, but also has great harm to human health [28].

However, there is relatively little research on the long-term accumulation of heavy metal $\mathrm{Cd}$ in soil. In China, the time of using reclaimed water for irrigation is still short, and the study of target heavy metals concentration in the soil and grain of the reclaimed water can't reflect the human health risk under the long-term irrigation of reclaimed water. Therefore, it is necessary to establish a model to predict the harm of accumulated heavy metals to the human health.

In this study, reclaimed water from Beijing was taken as the research object. Relevant experiments were carried out and the corresponding soil accumulated $\mathrm{Cd}$ concentration was predicted by HYDRUS-1D software for 100, 300 and 500 years of reclaimed water irrigation.

\section{Materials and methods}

\subsection{The material}

The tested soil is sandy loam (International), which was dried by indoor air and $2 \mathrm{~mm}$ screened to remove impurities. The soil column is made of plexiglass tube, $10 \mathrm{~cm}$ high and $5 \mathrm{~cm}$ the inner diameter. Before filling the soil column, the column and hemispherical funnel need to be washed by dilute acid solution to wash away the heavy metals which may be adsorbed, and the residual acid is washed with deionized water. Then, spread a 100-mesh screen over the perforated panel and cover the $1 \mathrm{~cm}$ thick 2$3 \mathrm{~mm}$ quartz sand. When filling the soil column, pack 2 times and each filling $5 \mathrm{~cm}$ according to the actual soil bulk density and the initial soil moisture content. The soil column is compacted with a plastic compactor to reach the required height and ensure that the bulk density of the soil column is the same as or comparable to the bulk density of the natural soil.

\subsection{Experimental devices}

Computer Digital Display Constant Current Pump DHL-2 made by Shanghai Jingke Industry Co., Ltd.; Oscillator THZ-92A made by Shanghai Boxun Industrial Co., Ltd.; Centrifuge TDL-40B made by Shanghai Anting Scientific Instrument Factory; pH meter pHS-3C made by Shanghai Precision Technology Co., Ltd.

\subsection{Soil column transport experiments}

With 2 L large beaker and constant flow pump as the water supply device, the water column was injected slowly into the saturated soil column to sufficiently remove air from the soil column. Then adjust the direction of the inflow fluid, so that it flows through the soil column from top to bottom, and the $\mathrm{CdCl}_{2}$ solution was input to the soil column at the speed of $0.05 \mathrm{~mL} / \mathrm{min}$. Finally, the flow liquid was collected by $50 \mathrm{~mL}$ centrifuge tube and the concentration of $\mathrm{Cd}$ ion in the liquid was determined. The experimental installation is shown in Figure 1. 


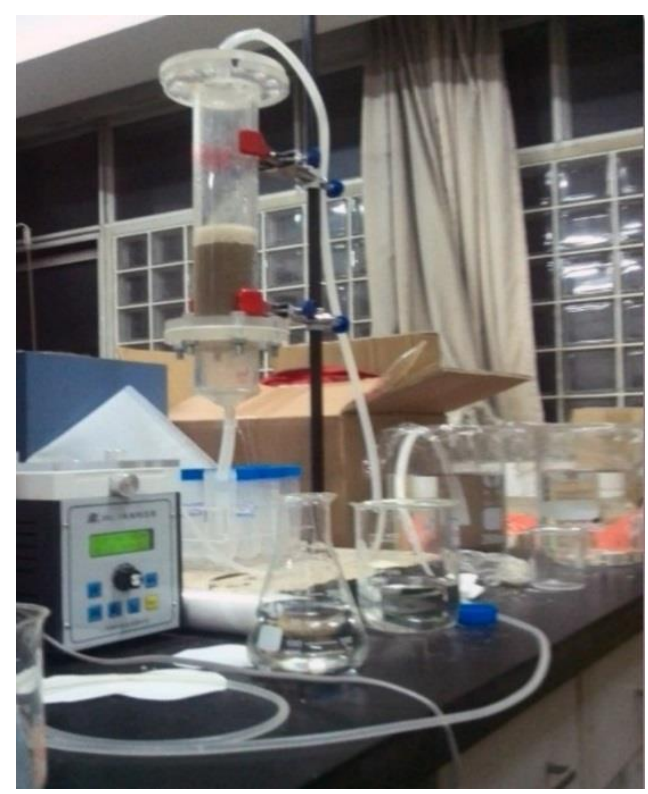

Figure 1. Experimental installation

\subsection{Cd Static Adsorption Test}

Batch equilibrium adsorption method was used to prepare cadmium nitrate solution with concentration gradients of 5,10,20,40,60,100,200,300, $400 \mathrm{mg} / \mathrm{L}$, using reclaimed water as mother liquor and adding cadmium nitrate (analytical purity). Then add $\mathrm{NaOH}$ or $\mathrm{HNO}_{3}$ to regulate $\mathrm{pH}$ same as the reclaimed water. Weigh accurately $2.00 \mathrm{~g}$ soil sample 9 times in $50 \mathrm{~mL}$ with round bottom plug plastic centrifuge tube, according to the 1:10 soil water ratio, pour into heavy metal solution $20 \mathrm{ml}$ with different concentration gradient, sealing stopper. In the constant temperature oscillator, keep the temperature of $25^{\circ} \mathrm{C}$ with $24 \mathrm{~h}$ shaking. Centrifuges were centrifuged at $3000 \mathrm{r} / \mathrm{min}$ and filtered after $10 \mathrm{~min}$, then the supernatant was collected. Determine the concentration of heavy metals by atomic absorption spectrophotometer.

Calculation formula of heavy metal adsorption amount:

$$
\mathrm{q}=\left(C_{i}-C_{e}\right) V / m
$$

In the formula, $\mathrm{q}$ is the amount of heavy metal adsorption, $\mathrm{mg} / \mathrm{kg} ; C_{i}$ and $C_{e}$ are added heavy metal concentration and equilibrium solution concentration, $\mathrm{mg} / \mathrm{L} ; \mathrm{V}$ is the volume of liquid at equilibrium, $\mathrm{L}$; and $\mathrm{m}$ is soil weight, $\mathrm{g}$.

In order to evaluate the adsorption of heavy metals in soil, Langmuir and Freundlich adsorption isotherms were used to fit them:

Freundlich:

$$
\mathrm{S}=K_{f} C^{\beta}
$$

Langmuir:

$$
\mathrm{S}=\frac{K_{d} C}{1+\eta C}
$$

In the formula, $S$ is adsorption capacity $(\mathrm{mg} / \mathrm{kg}), \mathrm{C}$ is concentration of solution $(\mathrm{mg} / \mathrm{L}), \mathrm{K}_{\mathrm{d}}, \mathrm{K}_{\mathrm{f}}, \beta, \eta$ are adsorption constant.

\subsection{Cl- Tracer Test}

The breakthrough curves of heavy metals with different treatments were obtained by a hybrid displacement experiment facility. After filling the soil column, open the peristaltic pump from the soil at the bottom of the column at a slower rate from input deionized water solution to saturated soil, to exclude the air in the soil column, and then adjust the flow into the liquid flow as the top-down 
through the soil column, thereby forming a stable flow field. The $\mathrm{CdCl}_{2}$ solution, $0.06 \mathrm{~mol} / \mathrm{L}$ concentration, is used as the inflow liquid, and injected into the soil column from the top of the soil column. The effluent was collected at regular intervals until the $\mathrm{Cl}^{-}$concentration in the effluent was close to the inlet liquid, and then stop the tracer test.

\subsection{Heavy Metal Leaching Experiment}

Because the concentration of heavy metals in reclaimed water was very low, in order to shorten the breakthrough time, heavy metals were added to the reclaimed water as the inflow liquid: Cd was $500 \mathrm{mg} / \mathrm{L}$. The process is similar to tracer test. The leachate collected at each time was stored in a plastic bottle (after pickling and removing heavy metals adsorbed on the surface) and stored in storage at 4 degrees.

\subsection{Software}

Origin 9.0, to compile the isotherm adsorption equation and fit the data of static adsorption experiment;

CXTFIT2.1, developed by American saline soil laboratory, to solve the inverse problem of convection dispersion equation for one-dimensional solute transport;

HYDRUS-1D, to predict the distribution and accumulation trend of heavy metal $\mathrm{Cd}$ in soil under the condition of reclaimed water irrigation.

\section{Results and discussions}

\subsection{Adsorption Test}

The two isothermal adsorption equations of self-defining function Freundlich and Langmuir were compiled by Origin 9.0 software, and the static adsorption test data of heavy metal $\mathrm{Cd}$ under $\mathrm{pH}=7$ condition were fitted. The result was shown in Figure 2.

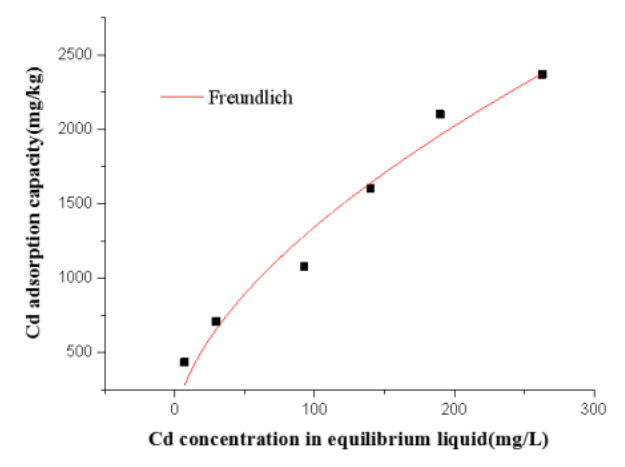

(a) Freundlich Isothermal adsorption model

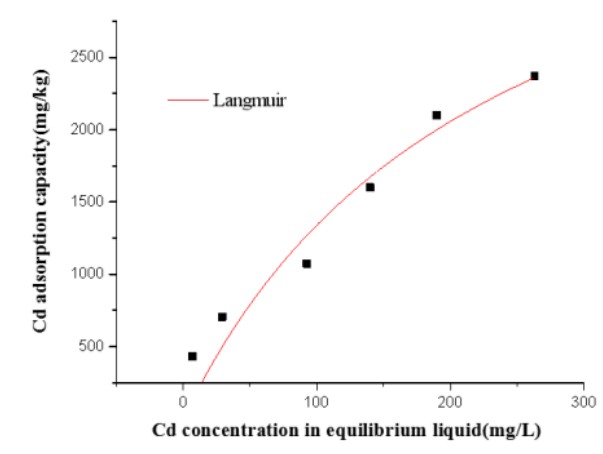

(b) Langmuir Isothermal adsorption model

Figure 2. The isothermal adsorption data and fitting curves of soil $\mathrm{Cd}$ when $\mathrm{pH}=7$ 
Table 1. The fitting parameters of soil isothermal adsorption equation when $p \mathrm{H}=7$

\begin{tabular}{cccccc}
\hline \multicolumn{7}{c}{ Freundlich } & \multicolumn{4}{c}{ Langmuir } \\
\hline $\mathrm{K}_{\mathrm{f}}$ & $\beta$ & $\mathrm{R}^{2}$ & $\mathrm{~K}_{\mathrm{d}}$ & $\eta$ & $\mathrm{R}^{2}$ \\
\hline 89.397 & 0.58867 & 0.9694 & 19.211 & 0.00434 & 0.9369 \\
\hline
\end{tabular}

From the above data, we can see that the fitting effects of Freundlich and Langmuir equations are good, and all of them are related to Cd. However, the certainty coefficient of Freundlich equation reaches 0.97 , so its equation is chosen as the soil adsorption parameter, which provides parameter support for the numerical simulation of soil movement.

\section{2. $\mathrm{Cl}^{-}$tracer test}

Based on CXTFIT 2.1 algorithm, the breakthrough curve of mixed displacement experiment is optimized by nonlinear least square method based on Levenberg-Marquardt algorithm, and the inverse problem of advection dispersion equation of one-dimensional solute transport is solved. For tracer Cl-, assuming that it does not react with the soil medium, given the $R=1$, the deterministic equilibrium model is used to estimate $\mathrm{D}$ and $\mathrm{V}$, as shown in Table 2 and Table 3.

Table 2. Fixed R, the parameters of Cl- BTC with the DEM model

\begin{tabular}{cccccc}
\hline Soil texture & $\begin{array}{c}\mathbf{V} \\
(\mathbf{c m} / \mathbf{m i n})\end{array}$ & $\begin{array}{c}\mathbf{D} \\
\left(\mathbf{c m}^{2} / \mathbf{m i n}\right)\end{array}$ & $\mathbf{R}$ & $\mathbf{r}^{\mathbf{2}}$ & MSE \\
\hline sandy clay loam & 0.0715 & 0.0457 & 1 & 0.9922 & 0.0009637 \\
\hline
\end{tabular}

V-Fitted mean pore flow velocity; D- Fitted dispersion coefficient; R- Retardation factor; $\mathrm{r}^{2}$ - Coefficient of determination; MSE- Mean square error.

Fixed V invariant, using deterministic equilibrium model to estimate D and R, as shown in Table 3.

Table 3. Fixed V, the parameters of Cl- BTC with the DEM model

\begin{tabular}{cccccc}
\hline Soil texture & $\begin{array}{c}\mathbf{V} \\
(\mathbf{c m} / \mathbf{m i n})\end{array}$ & $\begin{array}{c}\mathbf{D} \\
\left(\mathbf{c m}^{2} / \mathbf{m i n}\right)\end{array}$ & $\mathbf{R}$ & $\mathbf{r}^{2}$ & MSE \\
\hline sandy clay loam & 0.0711 & 0.0454 & 0.995 & 0.9922 & 0.0009637 \\
\hline V & 0.074 &
\end{tabular}

V- Mean pore flow velocity; D- Fitted dispersion coefficient; R-Fitted retardation factor; $\mathrm{r}^{2}$ - Coefficient of determination; MSE- Mean square error

Fixed R and V values, and used physical non-equilibrium TRM model to fit the breakthrough curve to estimate $\mathrm{D}, \beta$, and $\omega$, as shown in Table 4 .

Table 4. Fixed V and R, the parameters of Cl- BTC with the DEM model

\begin{tabular}{ccccccc}
\hline $\begin{array}{c}\mathbf{V} \\
(\mathbf{c m} / \mathbf{m i n})\end{array}$ & $\begin{array}{c}\mathbf{D} \\
\left(\mathbf{c m}^{2} / \mathbf{m i n}\right)\end{array}$ & $\mathbf{R}$ & $\boldsymbol{\beta}$ & $\boldsymbol{\omega}$ & $\mathbf{r}^{\mathbf{2}}$ & MSE \\
\hline 0.0711 & 0.0462 & 1.0 & 0.983 & 100 & 0.9921 & 0.00104 \\
\hline
\end{tabular}

$\mathrm{V}$ - measured mean pore flow velocity; D-fitted dispersion coefficient;

$\beta$-fitted partition coefficient; $\omega$-fitted mass transfer coefficient.

According to Tables 2-4, compared with the DEM model, TRM estimation of D value is not significantly different, but DEM model is more accurate. Therefore, it is suggested that the deterministic DEM equilibrium model be used to fit the breakthrough curves of Cl-.

\subsection{Heavy Metal Leaching and the Fitting of BTC}

In this experiment, the inversion function of HYDRUS-1D software and the chemical nonequilibrium two-point mathematical model (TSM) were used to fit the breakthrough curve of heavy metal Cd. The result was shown in Figure 3. 


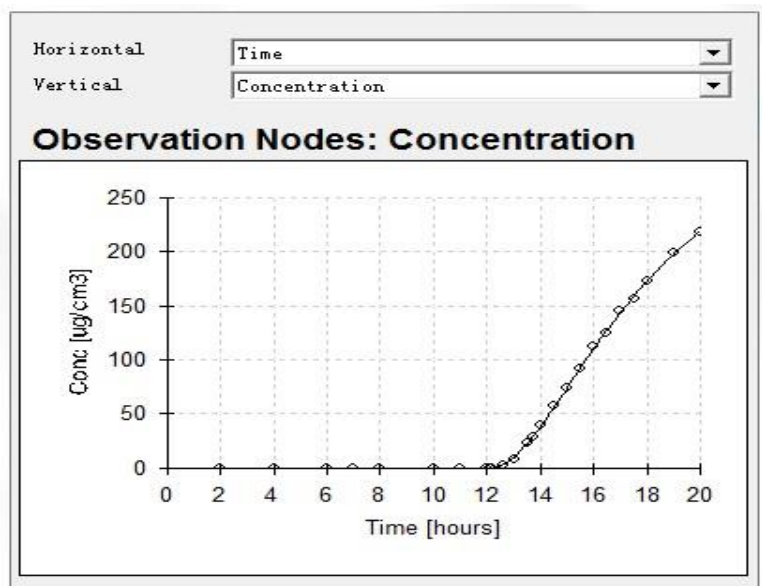

Figure 3. HYDRUS-1D Fitting the Cd breakthrough curve (BTC)

Table 5. The parameters obtained by Cd- BTC fitting with the TSM model

\begin{tabular}{ccccc}
\hline soil texture & element & f & $\alpha$ & $\mathbf{R}^{2}$ \\
\hline \multirow{2}{*}{ sandy clay loam } & $\mathrm{Cd}$ & 0.472 & 0.03811 & 0.99974 \\
\hline
\end{tabular}

where $f$ means the equilibrium adsorption point total adsorption point ratio; $\alpha$ means first-order kinetic rate coefficient; $\mathrm{R}^{2}$ means coefficient of determination, the closer to 1 , the better of fitting effect; the amount of value in brackets is the standard error coefficient, the smaller the better.

The Table 5 shown that: the effect of using the deterministic chemical non-equilibrium two-point model (TSM) to fit the breakthrough curve of Cd is very well, the coefficient of determination is close to 1 and the standard error coefficient is very small. The BTC is used to obtain soil transport parameters $\mathrm{f}$ and $\alpha$, which provided parameter support for prediction of heavy metal accumulation in reclaimed water under long-term irrigation conditions.

According to the experimental results and the mathematical model established, combined with the soil water parameters and movement parameters, using HYDRUS-1D software to predict the reclaimed water irrigation condition, distribution of heavy metal $\mathrm{Cd}$ in agricultural soils and accumulation trend. Tables 6 and 7 are the soil moisture parameters and soil transport parameters used in the HYDRUS-1D model, respectively. The predicted irrigation conditions are shown in Table 8.

Table 6. Soil moisture parameters

\begin{tabular}{ccccccc}
\hline soil texture & $\begin{array}{c}\mathbf{Q r} \\
\left(\mathbf{c m}^{\mathbf{3}} / \mathbf{c m}^{\mathbf{3}}\right)\end{array}$ & $\begin{array}{c}\mathbf{Q s} \\
\left(\mathbf{c m}^{\mathbf{3}} / \mathbf{c m}^{\mathbf{3}}\right)\end{array}$ & $\begin{array}{c}\mathbf{A} \\
\left(\mathbf{c m}^{-1}\right)\end{array}$ & $\mathbf{N}$ & $\begin{array}{c}\mathbf{K s} \\
(\mathbf{c m} / \mathbf{h})\end{array}$ & $\mathbf{1}$ \\
\hline sandy clay loam & 0.0569 & 0.531 & 0.0152 & 1.46 & 86.38 & 0.5 \\
\hline
\end{tabular}

Table 7. Soil movement parameters

\begin{tabular}{ccccccc}
\hline soil texture & $\begin{array}{c}\text { Bulk.D } \\
(\mathbf{g} / \mathbf{c m} 3)\end{array}$ & $\begin{array}{c}\text { Disp } \\
(\mathbf{c m})\end{array}$ & $\begin{array}{c}\mathbf{K}_{\mathbf{f}} \\
(\mathbf{L} / \mathbf{k g})\end{array}$ & $\mathbf{B}$ & $\mathbf{f}$ & $\mathbf{\alpha}$ \\
\hline sandy clay loam & 1.15 & 0.64 & 89.40 & 0.59 & 0.472 & 0.0381 \\
\hline
\end{tabular}

Table 8. Irrigation water quality

\begin{tabular}{cccccc}
\hline Reclaimed water process & $\mathbf{p H}$ & $\begin{array}{c}\mathbf{C d} \\
\mathbf{m g} / \mathbf{L}\end{array}$ & $\begin{array}{c}\mathbf{P b} \\
\mathbf{m g} / \mathbf{L}\end{array}$ & $\begin{array}{c}\mathbf{C u} \\
\mathbf{m g} / \mathbf{L}\end{array}$ & $\begin{array}{c}\mathbf{Z n} \\
\mathbf{m g} / \mathbf{L}\end{array}$ \\
\hline $\begin{array}{c}\text { Flocculation sedimentation sand } \\
\text { filtration }\end{array}$ & $6.4-9$ & 0.0013 & 0.0012 & 0.0017 & 0.013 \\
\hline
\end{tabular}


According to the cross-sectional area of the tested soil column (diameter $5 \mathrm{~cm}$ ), each column designed annual irrigation water consumption is $2 \mathrm{~L}$, irrigation flow is $0.5 \mathrm{~mL} / \mathrm{min}$, the actual amount of irrigation for one year is equivalent to HYDRUS-1D in the simulation of $66.67 \mathrm{~h}$ irrigation. The predicted irrigation years are 100, 300 and 500 years, and the corresponding HYDRUS-1D simulation time is $6667 \mathrm{~h}, 20000 \mathrm{~h}, 33333 \mathrm{~h}$, respectively. The predicted soil depth is $0 \sim 40 \mathrm{~cm}$. The numerical simulation results are shown in Figure 4.

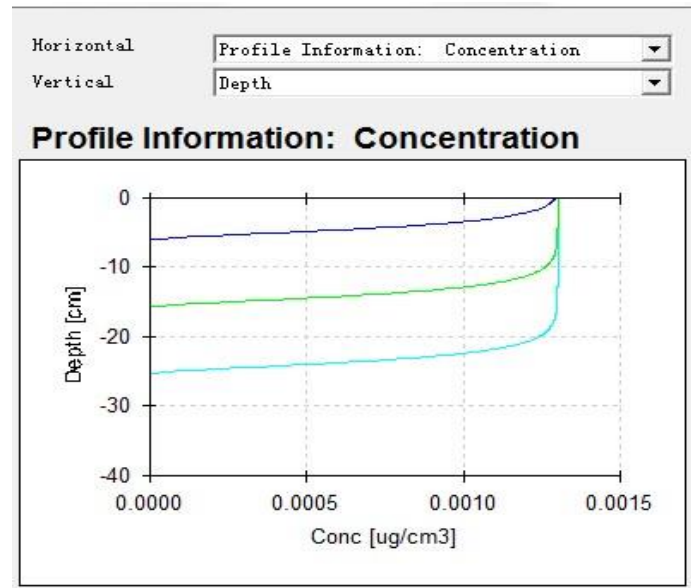

Figure 4. Distribution of $\mathrm{Cd}$ in soil solution during 100, 300 and 500 years of reclaimed water irrigation

Blue represents 100 years, green represents 300 years and the turquoise represents 500 years. In the simulation process, the density of the mesh of the soil profile is closely related to the stability of the prediction results. When the grid line in the concentration prediction of 251 below the large, unstable, but in more than 351 is basically stable, so there are 451 grid lines to discretize the soil profile, the relationship between the quantity and stability of grid line prediction results are shown in Table 9. Applied those parameters to the adsorption isotherm of Freundlich, the amount of heavy metals adsorbed by soil can be obtained. Heavy metals are easily adsorbed by soil matrix when they enter the soil, they are difficult to migrate in the soil profile and accumulate mainly in 0-20 cm top soil [29,30]. The concentration of soil solution is calculated from the average value of $0 \sim 20 \mathrm{~cm}$. The results are shown in Table 10.

Table 9. Meshing and stability relationship

\begin{tabular}{ccccccc}
\hline $\begin{array}{c}\text { Predicted irrigation } \\
\text { time }\end{array}$ & \multicolumn{5}{c}{ The migration depth of Cd corresponding to the number of mesh lines (cm) } \\
\cline { 2 - 7 } & 151 & 251 & 351 & 451 & 551 & 6 \\
\hline 100 year & 2.1 & 4.8 & 5.7 & 6 & 6 & 6 \\
\hline 300 year & 5.8 & 12.8 & 15 & 16 & 16 & 16 \\
\hline 500 year & 8.8 & 20.6 & 24 & 26 & 26 & 26 \\
\hline
\end{tabular}

Table 10. Accumulation of heavy metals in soil during simulated irrigation at 100, 300, and 500 years

\begin{tabular}{cccc}
\hline Predicted irrigation time & $\begin{array}{c}\text { HYDRUS-1D } \\
\text { Simulation time(h) }\end{array}$ & Heavy metal elements & $\begin{array}{c}\text { Soil accumulated } \\
\text { concentration(mg/kg) }\end{array}$ \\
\hline 100 year & 6667 & $\mathrm{Cd}$ & 0.742 \\
\hline 300 year & 20000 & $\mathrm{Cd}$ & 1.419 \\
\hline 500 year & 33333 & $\mathrm{Cd}$ & 1.783 \\
\hline
\end{tabular}

The national standard HJ 332-2006 specifies the limits of $\mathrm{Cd}$ in soil environment, $\leq 0.30 \mathrm{mg} / \mathrm{kg}$ $(p \mathrm{H} \leq 6.5) ; \leq 0.30 \mathrm{mg} / \mathrm{kg}(6.5<p \mathrm{H} \leq 7.5) ; \leq 0.60 \mathrm{mg} / \mathrm{kg}(p \mathrm{H}>7.5)$. From the data available in Table 11, the predicted content of soil heavy metal Cd may reach $0.742 \mathrm{mg} / \mathrm{kg}$, exceeded the limit value after 100 years of simulated irrigation. The accumulated concentration of heavy metal $\mathrm{Cd}$ in soil is 
relatively high after long-term irrigated by reclaimed water. In relevant research [31-36], also shown that long-term use of sewage irrigation, heavy metal pollutants like $\mathrm{Cd}, \mathrm{Cr}$, As et al in sewage are easy to deposit in the soil, which pollute the soil to a certain extent. Effective prevention and control measures should be taken. Furthermore, it is possible to enter the plant, food intake, accumulated in body, thus endangering human health [37-43] and also for some drug interferences [44,45].

\section{Conclusions}

In this paper, the cumulative risk of $\mathrm{Cd}$ in reclaimed water irrigated soil was analyzed and predicted. Firstly, according to the static adsorption experiment of sandy clay loam, the fitting effect of Freundlich equation on $\mathrm{Cd}$ is better for the certainty coefficient $\mathrm{R}^{2}$ reaches 0.97 . Then, use the more accurate DEM model of CXTFIT2.1 software to fit the $\mathrm{Cl}^{-}$penetration curve. Finally, made the heavy metal leading experiment, found that the TSM model has a good fitting effect on the penetration curve of $\mathrm{Cd}$, with a determination coefficient close to 1 and a small standard error coefficient. Based on the results of the above experiments, the prediction of heavy metal accumulation in soil under the condition of long-term irrigation of reclaimed water was predicted by HYDRUS-1D.The results shown that the predicted concentration of Cd in soil may reach $0.742 \mathrm{mg} / \mathrm{kg}, 1.419 \mathrm{mg} / \mathrm{kg}, 1.783 \mathrm{mg} / \mathrm{kg}$, after 100 years, 300 years, 500 years, respectively, which exceeded the national standard for soil environmental quality. Measures should be taken to reduce the risk of human health. How the heavy metals in soil migrate to human body through plants and animals and pose health risks to human body will be the focus of next research.

Acknowledgements: This work was financially supported by the National Water Special Subject titled Study on Safety Evaluation of Reclaimed Water Quality (No. 2008ZX07314-008-05). We are very grateful to Dr. C. Wang for providing reclaimed water and soil collection, thereby making our investigations possible.

\section{References}

1.LIANG, Y., LIN, Q., HUANG, P., WANG, Y., LI, J., ZHANG, L., CAO, J., A Rice Bioactive Peptide Binding with TLR4 to Overcome $\mathrm{H}_{2} \mathrm{O}_{2}$-Induced Injury in Human Umbilical Vein Endothelial Cells through NF-\#B Signaling. J. Agri. Food. Chem., 66(2), 2018, 440-448.

2. WANG, H., ZHONG, H., BO, G., Existing forms and changes of nitrogen inside of horizontal subsurface constructed wetlands. Environ. Sci. Poll. Res., 25(1), 2018, 771-781.

3. WANG, H., AN, X., ZHANG, Z., Effect of advanced treatment on ammonia nitrogen contained in secondary effluent from wastewater treatment plant. Fresenius. Environ. Bull., 27(4), 2018, $2043-$ 2050.

4. CAUNII1, A., NEGREA, A., PENTEA, M., SAMFIRA, I., MOTOC, M., BUTNARIU, M., Mobility of Heavy Metals from Soil in the Two Species of the Aromatic Plants. Rev. Chim., 66(3), 2015, 382-386.

5. MICLEAN, M., LEVEI, E. A., SENILA, M., ROMAN, C., CORDO, E., Assessment of Cu, Pb, Zn and Cd Availability to Vegetable Species Grown in the Vicinity of Tailing Deposits from Baia Mare Area. Rev. Chim., 60(1), 2009, 1-4.

6. PRUTEANU, A., VLADUT, V., CARDEI, P., BORDEAN, D., General Tendencies of the Behaviour of Vegetables Developed in a Soil Contaminated with Heavy Metals. Rev. Chim., 71(2), 2020, 85-90.

7. ALEAGHA, M. M., EBADI, A. G., Study of heavy metals bioaccumulation in the process of vermicomposting. Afr. J. Biotechnol., 10(36), 2011, 6997-7001.

8. KAZEMEINI, H. R., RAHIMI, E., KHARRATTAHERDEL, A. A., NOZARPOUR, N., EBADI, A. G., Cadmium concentration in muscle, liver and kidney of sheep slaughtered in Falavarjan abattoir, Iran. Toxic. Indu. Health., 26(5), 2010, 259-263.

9. EBADI, A. G., HISORIEV, H., Ecological Assessment of Heavy metals in Sediments of the 
Farahabad Region (Iran). Polish. J. Environ. Stud., 27(3), 2018, 1033-1039.

10.QAYYUM S., KHAN I., MENG K., ZHAO Y., PENG C., A review on remediation technologies for heavy metals contaminated soil. Cent. Asian. J. Environ. Sci. Technol. Innov., 1(1), 2020, 21-29.

11. NIE, Y., LUO, F., LIN, Q., Dietary nutrition and gut microflora: A promising target for treating diseases. Trends. Food. Sci. Technol., 75, 2018, 72-80.

12. Ma D., Xie H. Q., Zhang W., et al. Aryl hydrocarbon receptor activity of polyhalogenated carbazoles and the molecular mechanism[J]. The Science of the Total Environment, 2019, 687:516526.

13. WANG, L., LIN, Q., YANG, T., LIANG, Y., NIE, Y., LUO, Y., LUO, F., Oryzanol modifies high fat diet-induced obesity, liver gene expression profile, and inflammation response in mice. J. Agri. Food. Chem., 65(38), 2017, 8374-8385.

14. MALCHI, T., MAOR, Y., TADMOR, G., SHENKER, M., CHEFETZ, B., Irrigation of Root Vegetables with Treated Wastewater: Evaluating Uptake of Pharmaceuticals and the Associated Human Health Risks. Qual., 48, 2014, 9325-9333.

15. WEI, L. Y., LAN, W., LIN, Y., Accumulation characteristics of soil heavy metal CD in cassava and critical value of environmental safety. J. south. China. Agri., 03, 2012, 345-348.

16. LIU, Z., FENG, J., WANG, J., Resource-Constrained Innovation Method for Sustainability: Application of Morphological Analysis and TRIZ Inventive Principles. Sustainability, 12(3), 2020, 917.

17. LIU, Z., FENG, J., LIU, B., Pricing and service level decisions under a sharing product and consumers' variety-seeking behavior. Sustainability, 11(24), 2019, 6951.

18. SCUNTJENS, P., Aging effects on cadmium transport in undisturbed contaminated sandy soil columns. J. Environ. Qual., 30, 2001, 1040-1050.

19. DANIEL-TSANG, C. W., ZHANG, W. H., IRENE-LO, M. C., Modeling cadmium transport in soils using sequential extraction, batch, and miscible displacement experiments. Soil. Phys., 7l(3), 2007, 674-681.

20. GU, L.L., TENG, Z., YUAN, H., et al, Migration and enrichment study of $\mathrm{Cd}, \mathrm{Pb}$ and $\mathrm{Ni}$ in the soil of bauxite mining area. Anhui Agri. Sci. Bull,26(5),2020,95-96.

21. LU, H.F., QIAO D.M., QI X.B., et al., Effects of exogenous organic acids on soil pH, enzyme activity, and cadmium migration and transformation. J. Agro. Environ. Sci., 39(3), 2020, 542-553.

22. PANG, L.P., CLOSE, M., SCHNEIDER, D., STANTON, G. Effect of pore-water velocity on chemical nonequilibrium transport of $\mathrm{Cd}, \mathrm{Zn}$ and $\mathrm{Pb}$ in alluvial gravel columns. J. Contamin. Hydro., 57, 2002, 241-258.

23. DUBE, A., R., ZBYTNIEWSKI, A., Adsorption and Migration of Heavy Metalsin Soil . Polish. J. Environ. Stud., 10(1), 2001, 1-10.

24. RU, S. H., ZHANG, G. Y., SUN, S. Y., Migration and accumulation of heavy metals $\mathrm{Cu}, \mathrm{Zn}, \mathrm{Pb}$ and CD in soil - radish system. J. North. China. Agri., S1, 2013, 361-365.

25. LI, Y., ZHANG, J. Z., TONG, H. R., Absorption and Accumulation of Heavy Metal $\mathrm{Pb} \mathrm{Cu} \mathrm{Cd}$ and Cr in Tea Seedlings. J. Agri. Environ. Sci., 03, 2009, 454-459.

26. YANG, Y., WU, Z. P., ZHANG, M., Preliminary Study on Absorption Characteristics and Accumulation of Heavy Metal Cd in Polygonum. J. Agri. Environ. Sci., 11, 2010, 2094-2099.

27. BANG, S. L., Environmental pollution of the Japanese Minamata disease incident. Renmin. Gongan., 2, 2016, 74-78.

28. Zhang, Y. X., Yu, F., Zhang, Y. Y., Absorption transport and accumulation mechanism of heavy metal cadmium in plants. Chin. J. Eco-Agri., 05, 2008, 1317-1321.

29. ANDERSSON, A., NILSSON, K. O., Enrichment of trace elements from sewage sludge fertilizer in soils and plants. Ambio., 1(5), 1972, 176-179.

30. SINGH, S. P., MA, L. Q., TACK, F. M. G., Trace metal leachability of land-disposed dredged sediments. J. Environ. Qual., 29(4), 2000, 1124-1132.

31. ZHANG, M. K., WANG, L. P., Impact of Heavy Metals Pollution on Soil Organic Matter 
Accumulation. Chin. J. Appl. Ecol., 18(7), 2007. 1479-1483.

32. YANG, Q. W., SHU, W. S., LIN, Z., Compound Pollution and Ecological Evaluation of Heavy Metals from Mining Waste Water to Soil-Rice Plant System. J. Agro-Environ. Sci., 22(4), 2003, 385390.

33. ZHAO, Q. Y., LI, D. J., SUN, H. X., Review of Study on Effect of Reclaimed Water Irrigation on Soil Quality. Water. Sav. Irrigat., 1, 2017, 53-58.

34. CHIOU, R. J,. Risk assessment and loading capacity of reclaimed wastewater to be reused for agricultural irrigation. Environ. Monit. Assess.,142, 2008, 255-262.

35. ZHANG, S. H., SHEN, Y. W., Danger to Soil by Heavy Metals Pollution from Polluted Irrigation. Admin. Techniq. Environ. Monitor., 12(2), 2000, 22-24.

36. PINTO, U., MAHESHWARI, B. L., GREWAL, H. S., Effects of greywater irrigation on plant growth,water use and soil properties. Resource. Conserv. Recycl., 54(7), 2010, 429-435.

37. HAMILTON, J. A., Transactions on Environment and Development. WSEAS, 2(2), 2006, 117-129

38. INGWERSEN, J., STRECK, T., Modeling the Environmental Fate of Cadmium in a Large Wastewater Irrigation Area. Environ. Qual., 35(5), 2006, 1702-1714.

39. FERREL, R. E., AAGAARD, P., FORSMAN, J., Application of a geochemical transport model to predict heavy metal retention $(\mathrm{Pb})$ by clay liners. Appl. Clay. Sci., 21, 2002, 59-66.

40. HE, W., WANG, F. H., LI, M. Y., Effects of Pb, Cd and Hg Combined Pollution on the Growth and Heavy Metal Accumulation. J. Jiangxi. Agri. Sci., 12, 2011, 41-44.

41. GU, F., GUO, J., ZHANG, W., SUMMERS, P. A., HALL, P., From waste plastics to industrial raw materials: A life cycle assessment of mechanical plastic recycling practice based on a real-world case study. Sci. Total. Environ., 601, 2017, 1192-1207.

42. GU, F., ZHANG, W., GUO, J., HALL, P., Exploring "Internet+ Recycling": Mass balance and life cycle assessment of a waste management system associated with a mobile application. Sci. Total. Environ., 649, 2019, 172-185.

43. GU, F., MA, B., GUO, J., SUMMERS, P. A., HALL, P., Internet of things and Big Data as potential solutions to the problems in waste electrical and electronic equipment management: An exploratory study. Waste. Management., 68, 2017, 434-448.

44. GAO, W., WANG, Y., WANG, W., SHI, L., The first multiplication atom-bond connectivity index of molecular structures in drugs. Saudi. Pharm. J., 25(4), 2017, 548-555.

45. GAO, W., WANG, Y., BASAVANAGOUD, B., JAMIL, M. K., Characteristics studies of molecular structures in drugs. Saudi. Pharm. J., 25(4), 2017, 580-586.

Manuscript received: 20.03 .2020 